\title{
Investigation of ancient DNA to enhance natural history museum collections: misidentification of smooth-coated otter (Lutrogale perspicillata) specimens across multiple museums
}

\author{
Filippo Barbanera ${ }^{1, *}$, Beatrice Moretti ${ }^{1}$, Monica Guerrini' ${ }^{1}$, \\ Omar F. Al-Sheikhly ${ }^{2}$ \& Giovanni Forcina ${ }^{1,3}$
}

\author{
1 Department of Biology, Zoology-Anthropology Unit, Via A. Volta 4 - 56126 Pisa, Italy. \\ 2 Department of Biology, University of Baghdad, Al-Jadriya - 10071 Baghdad, Iraq. \\ ${ }^{3}$ Current affiliation: Conservation and Evolutionary Genetics Group, Estación Biológica de Doñana (EBD-CSIC), 41092 \\ Sevilla, Spain. \\ * Corresponding author: filippo.barbanera@unipi.it
}

\begin{abstract}
Historical and modern natural museum collections are storehouses of extraordinary value for scientific research in a wide range of fields. Recent advances in molecular biotechnology (e.g., next generation genomics) have increased the range of collection material employable for DNA-based analyses to unprecedented levels. Nevertheless, the value of museum specimens strictly depends on reliability of data associated with them. We report on investigations of ancient DNA from specimens of smooth-coated otter (Lutrogale perspicillata, Mustelidae), the largest otter species living in Asia, in US and European mammal collections. Mitochondrial DNA Cytochrome- $b$ gene sequencing proved that the studied specimens were not the expected taxon. Indeed, they actually belonged to three different species, namely the Asian small-clawed (Aonyx cinereus), Eurasian (Lutra lutra) and African clawless (Aonyx capensis) otters. This represents the first record of mustelid misidentification from museum collections. Detection of errors can be extremely difficult when based only on collectors' notes and data. Hence, we warn scientists involved in otter research about potential challenges when dealing with museum specimens. We recommend curators pursue a multidisciplinary approach, including DNA analyses, to accurately catalogue the resources under their management and uphold the value of biodiversity information.
\end{abstract}

KEY WORDS: error, genetic identity, mistaken cataloguing, mitochondrial DNA, specimen label

\section{INTRODUCTION}

Natural history museums first appeared in Europe during XVI century as cabinets of curious, artificial and natural items (wunderkammer) for nobles, dealers and travellers. Since then, they have progressively grown in relevance as authentic scientific collections, and support research in a wide range of fields, from systematics to ecology and evolutionary biology (THOMAS, 1994; WeSCHLER, 1995). In the 1980s, PCR-based techniques also allowed retrieval of molecular information from museum specimens. Rapidly, pioneering studies obtained the first DNA sequences from extinct taxa (HIGUCHI et al., 1984; THOMAS et al., 1989), and collections began to play a role as potential storehouses of astonishing value for a huge array of scientific investigations (GEE, 1988; GRAVES \& BRAUN, 1992).

The more refined the molecular-genetic techniques became, the more appealing were museum specimens, even in ways that the original collector had never imagined before (e.g., next generation genomics: BI et al., 2013). Funding shortages to support wide-ranging and long-lasting sampling in the wild, sociopolitical instability of study areas, rarity and/ or elusiveness of taxa (especially if at risk of extinction), and the need for ecological data series, were all factors that fuelled a growing interest in museum specimens (e.g., SUAREZ \& TSUTSUI, 2004; WANDELER et al., 2007; LISTER 
\& Climate Change Research Group, 2011). Hence, DNA study of material in collections increased to unprecedented levels. If specimens are to be an essential tool in research, their value depends completely on reliability of data associated with them (BOESSENKOOL et al., 2010). Therefore, errors (taxonomic identity, origin, gender, etc.) disclosed by recent DNAbased investigations have been vital findings for the management of museum biodiversity resources. However, these studies focused on mammals (Panthera: BARNETT et al., 2007; Bradypus: DE MORAES-BARROS et al., 2011; rodents: MÜLLER et al., 2013; RoBINS et al., 2014) and birds only (Gallinula: LEE \& GRIFFITHS, 2003; Megadyptes: BoESSENKOOL et al., 2010; Acrocephalus: KoBliK et al., 2011; Leucocarbo: RAWLENCE et al., 2014; Francolinus: FORCINA et al., 2015).

Otters (Mustelidae, Carnivora) include 13 species living on all continents except Antarctica and Australasia. Despite some being diurnal, otters are elusive and cryptic in habit, and they can be difficult to observe in the wild. For this reason, most studies rely on non-invasive sampling methods (faeces: e.g., LERONE et al., 2014), roadkilled (or died from other causes) individuals (e.g., KoEPFLI et al., 2008a) and museum frozen tissue collections (e.g., KOEPFLI et al., 2008b) to increase sample size obtained from wildcaptured animals. This is the case also for the smooth-coated otter (Lutrogale perspicillata), the largest living Asian otter, whose distribution range encompasses socio-politically unstable and remote areas, as the species occurs in Iraq with an isolated population (AL-SHEIKHLY \& NADER, 2013; AL-SHEIKHLY et al., 2015a, b), and from Pakistan across India to southern China, Indochina and extreme southeastern Asia (Java and Borneo). The species is listed as Vulnerable by IUCN and its patchy population has globally declined by $30 \%$ over the past 30 years, meaning that in some place otters are now locally extinct (HWANG \& LARIVIÈRE, 2005; HUSSAIN et al., 2008; YOXON \& YOXON, 2014). In addition, unlike the Eurasian (Lutra lutra) and the Asian small-clawed (Aonyx cinereus) otter, live individuals of $L$. perspicillata are only kept in ex situ institutions in low numbers. Therefore, specimens resident in museum collections can represent a highly valuable resource for conservation, ecological, biogeographical and evolutionary research.

In this paper, we report on investigation of ancient DNA from otters labelled as L. perspicillata and resident in mammal collections of US and European museums. We have proved that these specimens belong to three different species, two sympatric with the smoothcoated otter in the region where they were collected, and one living in the African continent. We emphasize the need for a multidisciplinary approach, including DNA analyses, to properly identify museum otters.

\section{MATERIALS AND METHODS}

\section{Museum specimen sampling}

We borrowed samples from five otter specimens resident in the mammal collections of the natural history museums of Chicago, Paris and Vienna (Table 1). Curators provided a tiny amount $(<5 \mathrm{mg}$ ) of dry skin from the skull cavity (e.g., turbinates). Alternatively, we acquired slivers of toe pad. All specimens were catalogued as Lutrogale perspicillata, a taxon included in the Appendix II of CITES. Samples were shipped to the Department of Biology of Pisa, registered (IT 027 code) as CITES exempt scientific institution.

\section{DNA extraction, amplification and sequencing}

DNA was extracted in a dedicated room free of any mammal DNA in the Anthropology building of the Department of Biology (ZoologyAnthropology Unit). Workflow was conducted in strict conformity to ancient DNA protocols throughout all steps, including physically isolated pre-PCR and post-PCR working areas and with ad hoc equipment. UV light and 10\% bleach were routinely used to sterilize the 
Table 1

Museum specimens investigated in this study. $*$ = referred to as from either French Indochina (original label) or Vietnam (specimen box); $* *=$ skin bought at the market of Kathmandu; ? = not determined.

\begin{tabular}{|c|c|c|c|c|c|c|c|c|c|c|}
\hline $\begin{array}{l}\text { Specimen } \\
\text { label }\end{array}$ & Museum & Specimen code & Sex & Age & Region & Locality & Date & Sample & Genetic ID & GenBank \\
\hline $\begin{array}{l}\text { Lutrogale } \\
\text { perspicillata }\end{array}$ & $\begin{array}{l}\text { Field Museum of } \\
\text { Natural History, } \\
\text { Chicago, USA }\end{array}$ & FMNH 37890 & $\hat{\sigma}$ & $\begin{array}{l}\text { A few } \\
\text { weeks }\end{array}$ & Laos PDR & $\begin{array}{l}\text { Thateng (Plateau } \\
\text { des Bolovens: } \\
\text { Lat. } 15^{\circ} 33^{\prime} \mathrm{N} \text {, } \\
\text { Long. } 106^{\circ} 33^{\prime} \mathrm{E} \text { ) }\end{array}$ & 25 Dec. 1931 & $\begin{array}{l}\text { Skin from } \\
\text { skull }\end{array}$ & Aonyx cinereus & LT220225 \\
\hline $\begin{array}{l}\text { Lutrogale } \\
\text { perspicillata }\end{array}$ & $\begin{array}{l}\text { Field Museum of } \\
\text { Natural History, } \\
\text { Chicago, USA }\end{array}$ & FMNH 37891 & q & $\begin{array}{l}\text { A few } \\
\text { weeks }\end{array}$ & Laos PDR & $\begin{array}{l}\text { Thateng (Plateau } \\
\text { des Bolovens: } \\
\text { Lat. } 15^{\circ} 33^{\prime} \mathrm{N} \text {, } \\
\text { Long. } 106^{\circ} 33^{\prime} \mathrm{E} \text { ) }\end{array}$ & 25 Dec. 1931 & $\begin{array}{l}\text { Skin from } \\
\text { skull }\end{array}$ & Aonyx cinereus & LT220225 \\
\hline $\begin{array}{l}\text { Lutrogale } \\
\text { perspicillata }\end{array}$ & $\begin{array}{l}\text { National Museum } \\
\text { of Natural History, } \\
\text { Paris, France }\end{array}$ & $\begin{array}{l}\text { MN H N - Z M - } \\
\text { MO 1883-1295 }\end{array}$ & $\widehat{\delta}$ & $\begin{array}{l}\text { Juve- } \\
\text { nile }\end{array}$ & Philippines & $\begin{array}{l}\text { Puerto Princesa, } \\
\text { Palawan Is. }\end{array}$ & 1883 & Toe pad & Aonyx cinereus & LT220226 \\
\hline $\begin{array}{l}\text { Lutrogale } \\
\text { perspicillata }\end{array}$ & $\begin{array}{l}\text { National Museum } \\
\text { of Natural History, } \\
\text { Paris, France }\end{array}$ & $\begin{array}{l}\text { M N H - Z M - } \\
\text { MO 1962-1646 }\end{array}$ & q & Adult & Indochina & Unknown* & 1962 & $\begin{array}{l}\text { Skin from } \\
\text { skull }\end{array}$ & Aonyx capensis & LT220227 \\
\hline $\begin{array}{l}\text { Lutrogale } \\
\text { perspicillata }\end{array}$ & $\begin{array}{l}\text { Natural History } \\
\text { Museum, Vienna, } \\
\text { Austria }\end{array}$ & NMW 43414 & $?$ & $?$ & Nepal & Kathmandu** & 1978 & Toe pad & Lutra lutra & LT220228 \\
\hline
\end{tabular}

surfaces of benches and laboratory devices, and to get rid of any possible contaminant DNA. The reliability of each DNA extraction was monitored through two blank controls. A small amount $(2 \mathrm{mg})$ of starting material was removed from each sample and minced, employing a sterile disposable razor blade (BBraun, Aesculap Division). DNA was isolated using the QIAamp DNA Micro Kit (Qiagen) in compliance with the manufacturer's instructions, modified as follows when dealing with hard tissues: (i) incubation in a shaking water bath up to $48 \mathrm{~h}$; (ii) use of $4 \mu \mathrm{l}$ of dithiothreitol (Fluka, $4 \mathrm{mg} / \mathrm{ml}$ ) every $24 \mathrm{~h}$ of incubation; (iii) twofold addition of proteinase $\mathrm{K}$ (Sigma Aldrich, $20 \mathrm{mg} / \mathrm{ml}$ ); (iv) repeated freezing and thawing of the supernatant, as it separated out residual proteins and other substances that seemed to inhibit PCR (PERGAMS \& LACY, 2008). We amplified two overlapping $211 \mathrm{bp}-$ long and 199 bp-long mitochondrial DNA (mtDNA) Cytochrome- $b$ gene (Cyt- $b$, total length: 1,140 bp) fragments in two distinct PCR reactions using primers reported in Table 2. Final (fragment $1+$ fragment 2) 307 bp-long sequence corresponded to the Cyt- $b$ portion comprised between nucleotide (nt) position n. 602 and n. 908 (codon reading frame $=2$ ). PCR reactions $(50 \mu \mathrm{l})$ were prepared as follows: $1 \mu \mathrm{l}$ of AmpliTaq Gold DNA Polymerase (1 U/ $\mu 1$, Applied Biosystems),
$4 \mu \mathrm{l} 25 \mathrm{mM} \mathrm{MgCl}$ (Applied Biosystems), $5 \mu \mathrm{l}$ of 10x PCR Gold buffer (Applied Biosystems), $5 \mu 12.5 \mathrm{mM}$ dNTP (Sigma Aldrich), $3 \mu \mathrm{l}$ of each primer $(1 \mu \mathrm{M}), 1 \mu \mathrm{l}$ of DNA template and $1 \mu \mathrm{l}$ of $75 \mu \mathrm{M}$ Bovine Serum Albumin (4 mg/ml, Sigma Aldrich) to prevent proteins from inhibiting PCR (РÄÄBO et al., 1988). We carried out PCRs in an Eppendorf Master Cycler Personal (v5332) including two blank controls to check for cross contaminations. Thermal profile was as follows: $10 \mathrm{~min}$ at $94^{\circ} \mathrm{C}$; then, 70 cycles at $94^{\circ} \mathrm{C}$ for $45 \mathrm{~s}$, $50^{\circ} \mathrm{C}$ for $45 \mathrm{~s}$, and $72^{\circ} \mathrm{C}$ for $45 \mathrm{~s}$; final extension, $72^{\circ} \mathrm{C}$ for $10 \mathrm{~min}$. We purified PCR products using the Genelute PCR Clean-up Kit (volume $40 \mu \mathrm{l}$; Sigma Aldrich), and we directly sequenced them twice on both DNA strands (BigDye ${ }^{\circledR}$ Terminator v3.1 Cycle Sequencing Kit, ABI 3730 DNA automated sequencer, Applied Biosystems) at Genechron (ENEA, Rome, Italy).

\section{Genetic analyses}

Chromas v2.01 (http://chromas-lite.software. informer.com/2.0) was used to read ABI electropherograms, whereas ClustalX v1.81 (THOMPSON et al., 1987) was used to align partial Cyt- $b$ sequences with those downloaded from the National Center for Biotechnology 
Table 2

Primers used for the amplification of the two mtDNA Cyt- $b$ fragments of this study.

\begin{tabular}{ccc}
\hline Primer & 5'-3' sequence & PCR product \\
\hline Fw_583 & GTTCACCTCCTGTTTCTCC & 211 bp-long Cyt- $b$ (fragment 1) \\
Rev_794 & GGTGTACTGAGCGGGTTGGC & $211 \mathrm{bp}$-long Cyt- $b$ (fragment 1) \\
Fw_727 & GTACTATTCTCCCCAGACCT & 199 bp-long Cyt- $b$ (fragment 2) \\
Rev_926 & GAGGTGTGTAGCAGTGGGACG & 199 bp-long Cyt- $b$ (fragment 2) \\
\hline
\end{tabular}

Information (GenBank) and dealing with 12 out of 13 known otter species. These sequences were obtained from KOEPFLI et al. (2008a) with the exception of Lontra provocax (southern river otter: ViANNA et al., 2011). No GenBank record was available for Aonyx congicus (Congo clawless otter). We used Mega v5 (TAMURA et al., 2011) to calculate nucleotide composition and transitions: transversions ratio $(\mathrm{Ti} / \mathrm{Tv})$. Comparative sequence analyses were carried out using BioEdit v5.0.9 (HALL, 1999) to compute nucleotide difference count matrix for the whole alignment and to identify polymorphic sites among $A$. cinereus, A. capensis, L. lutra, L. perspicillata and the investigated museum specimens. Then, we produced a Maximum Likelihood (ML) tree choosing Pteronura brasiliensis (giant otter) as outgroup according to the molecular phylogeny of KOEPFLI et al. (2008b). However, no attempt was made to reconstruct the evolutionary relationships within Lutrinae due to the constraints of using a short fragment from a single genetic marker. We carried out a robust heuristic tree reconstruction in order to assign sequences retrieved from museum specimens to GenBank otter records. Following GUINDON et al. (2010), we used Smart Model Selection at PhyML (South of France Bioinformatic Platform, www.atgc-montpellier. fr) and we found that the TN93 (TAMURA \& NEI, $1993)+\mathrm{G}$ (a shape parameter $=3.69$, with six substitution rate categories) + I (proportion of invariable sites $=0.54$ ) was the best evolutionary model fitting to our dataset according to both Akaike $(=2804.8)$ and Bayesian (= 2946.4) Information Criterion. We used these parameters to carry out an ML reconstruction using NearestNeighbour Interchanges to swap adjacent tree branches (with active topology/branch length improving options). Statistic support at each node was evaluated by bootstrapping percentage (BP, with 1,000 replicates: FELSENSTEIN, 1985).

\section{RESULTS}

Electropherograms were identical with each other for each specimen analysed in the study. Overall, we found average unequal nucleotide composition typical of animal mtDNA: $29.1 \%$ of adenine, $22.1 \%$ of thymine, $36.0 \%$ of cytosine, and $12.8 \%$ of guanine. The number of Ti was 9.1 times higher than that of Tv, on average. We did not detect any internal stop codon/indels. Then, the real mtDNA nature of the five PCR products was assessed, and the potential occurrence of any nuclear sequence of mitochondrial origin (Numt: sensu LOPEZ et al., 1994) was ruled out.

None of the sequenced specimens turned out to be $L$. perspicillata as was expected according to their labels, three (FMNH 37890-1 and MNHNZM-MO 1883-1295) being assigned to Aonyx cinereus, one (MNHN-ZM-MO 1962-1646) to A. capensis and one (NMW 43414) to Lutra lutra (Table 1). When the average number of nucleotide differences among otter species was taken into account, we found that it ranged between 7 (over $307 \mathrm{nt}, 2.3 \%$ : L. provocax vs. Lontra felina) and 71 (over 307 nt, 23.1\%: Pteronura brasiliensis vs. Hydrictis maculicollis) (Table 3). In particular, FMNH 37890 and FMNH 37891 sequences were $100 \%$ identical to A cinereus AF057119 GenBank entry, while MNHN-ZM-MO 18831295 diverged from the latter by two nucleotide substitutions ( $=99.3 \%$ of identity); MNHN-ZMMO 1962-1646 and NMW 43414 were 100\% identical to A. capensis AF057118 and L. lutra 
Table 3

Nucleotide difference count matrix as inferred from aligned 307 bp-long mtDNA Cyt- $b$ sequences. Legend: Lfel, Lontra felina (marine otter); Lpro, Lontra provocax (southern river otter); Llon, Lontra longicaudis (Neotropical otter); Lcan, Lontra candensis (North American river otter); Llut, Lutra lutra (Eurasian otter); 43414, NMW 43414 specimen; Lsum, Lutra sumatrana (hairy-nosed otter); Acin, Aonyx cinereus (Asian smallclawed otter); 37890, FMNH 37890 specimen; 37891, FMNH 37891 specimen; 1883, MNHN-ZM-MO 18831295 specimen; Lper, Lutrogale perspicillata (smooth-coated otter); Acap, Aonyx capensis (African clawless otter); 1962, MNHN-ZM-MO 1962-1646 specimen; Hmac, Hydrictis maculicollis (spotted-necked otter); Elut, Enhydra lutris (sea otter); Pbra, Pteronura brasiliensis (giant otter). GenBank code of each otter sequence used in this matrix is reported in Fig. 1 and Table 1.

\begin{tabular}{|c|c|c|c|c|c|c|c|c|c|c|c|c|c|c|c|c|c|}
\hline & Lfel & Lpro & Llon & Lcan & Llut & 43414 & Lsum & Acin & 37890 & 37891 & 1883 & Lper & Acap & 1962 & Hmac & Elut & Pbra \\
\hline Lfel & - & & & & & & & & & & & & & & & & \\
\hline Lpro & 7 & - & & & & & & & & & & & & & & & \\
\hline Llon & 19 & 12 & - & & & & & & & & & & & & & & \\
\hline Lcan & 31 & 24 & 28 & - & & & & & & & & & & & & & \\
\hline Llut & 53 & 50 & 52 & 50 & - & & & & & & & & & & & & \\
\hline 43414 & 53 & 50 & 52 & 50 & 0 & - & & & & & & & & & & & \\
\hline Lsum & 56 & 51 & 47 & 47 & 26 & 26 & - & & & & & & & & & & \\
\hline Acin & 48 & 43 & 42 & 45 & 36 & 36 & 30 & - & & & & & & & & & \\
\hline 37890 & 48 & 43 & 42 & 45 & 36 & 36 & 30 & 0 & - & & & & & & & & \\
\hline 37891 & 48 & 43 & 42 & 45 & 36 & 36 & 30 & 0 & 0 & - & & & & & & & \\
\hline 1883 & 48 & 43 & 43 & 47 & 36 & 36 & 30 & 2 & 2 & 2 & - & & & & & & \\
\hline Lper & 52 & 47 & 47 & 49 & 30 & 30 & 29 & 25 & 25 & 25 & 25 & - & & & & & \\
\hline Acap & 58 & 55 & 53 & 50 & 33 & 33 & 26 & 32 & 32 & 32 & 34 & 29 & - & & & & \\
\hline 1962 & 58 & 55 & 53 & 50 & 33 & 33 & 26 & 32 & 32 & 32 & 34 & 29 & 0 & - & & & \\
\hline Hmac & 59 & 54 & 56 & 54 & 45 & 45 & 43 & 47 & 47 & 47 & 49 & 50 & 45 & 45 & - & & \\
\hline Elut & 59 & 55 & 54 & 54 & 41 & 41 & 38 & 45 & 45 & 45 & 47 & 41 & 35 & 35 & 51 & - & \\
\hline Pbra & 66 & 63 & 57 & 57 & 50 & 50 & 56 & 57 & 57 & 57 & 59 & 59 & 56 & 56 & 71 & 57 & - \\
\hline
\end{tabular}

AF057124, respectively. Polymorphic sites for A. cinereus, L. perspicillata, A. capensis, L. lutra and museum specimens were included in Table 4. In agreement with what is reported above, ML reconstruction (Fig. 1) assigned specimens FMNH 378901-1 and MNHN-ZMMO 1883-1295 to $A$. cinereus $(\mathrm{BP}=95 \%)$, and MNHN-ZM-MO 1962-1646 and NMW 43414 to $A$. capensis and L. lutra, respectively $(\mathrm{BP}=$ $100 \%$, both clusters).

\section{DISCUSSION}

The very large majority of museum specimens are correctly classified and catalogued. However, a small percentage includes various types of misinformation. Far from wanting to suggest that museum collections are somehow untrustworthy, we have reported some examples of smoothcoated otter misidentification in order to avoid perpetuation of errors and provide curators with correct information to enhance the value of their collection. Likewise, we warn scientists involved in otter research about such potential trouble. In this study, mtDNA Cyt- $b$ gene sequencing indicated that five museum specimens recorded as Lutrogale perspicillata were incorrectly identified, as they belonged instead to three different species such as the Asian small-clawed (A. cinereus), Eurasian (L. lutra) and African clawless (A. capensis) otter. To the very best of our knowledge, these results represent the first record of mustelid misidentification from museum collection. 


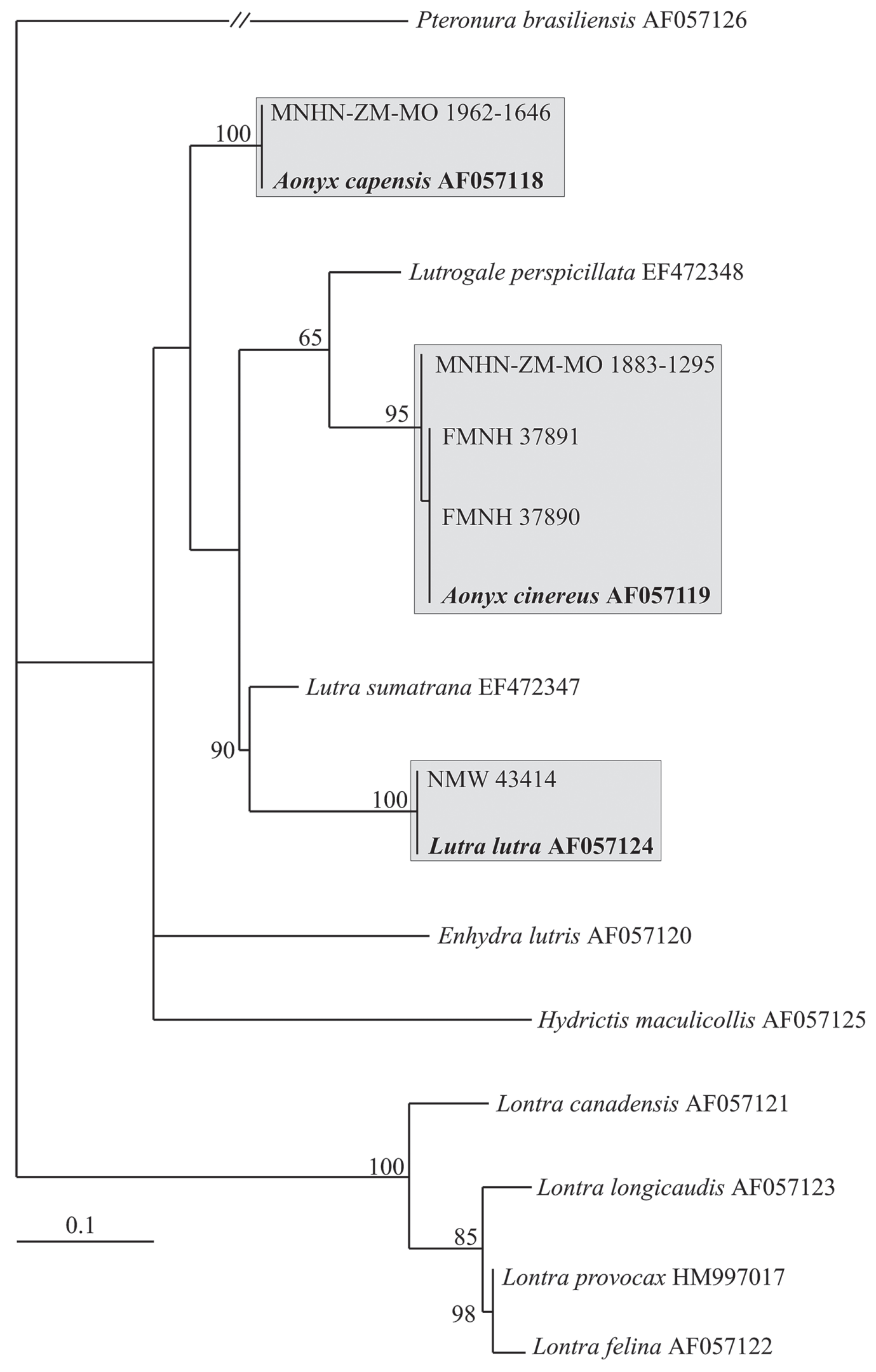

Fig. 1. - Maximum Likelihood tree reconstruction as obtained with PhyML using 307 bp-long mtDNA Cyt- $b$ sequences of this study. Statistic support (bootstrapping percentage) is reported above each node when $>50 \%$. Scale bar is proportional to the number of substitutions per site. GenBank sequences were all obtained from KoEPFLI et al. (2008a) with the exception of L. provocax (VIANNA et al., 2011). No genetic record was available for $A$. congicus. For detail on each species see YOXON \&YOXON (2014). 
Table 4

Polymorphic sites for A. cinereus, L. perspicillata, A. capensis, L. lutra and investigated museum specimens from aligned sequences. Dots refer to nucleotides that are identical in state. Nucleotide position number based on position within the alignment (1-307). Legend: 37890, FMNH 37890 specimen; 37891, FMNH 37891 specimen; Acin, Aonyx cinereus (GenBank code: AF057119); 1883, MNHN-ZM-MO 1883-1295 specimen; Lper, Lutrogale perspicillata (GenBank code: EF472348); Acap, Aonyx capensis (GenBank code: AF057118); 1962, MNHN-ZM-MO 1962-1646 specimen; Llut, Lutra lutra (GenBank code: AF057124); 43414, NMW 43414 specimen.

\begin{tabular}{|c|c|c|c|c|c|c|c|c|c|c|c|c|c|c|c|c|c|c|c|c|c|c|c|c|c|c|c|c|}
\hline & 1 & 3 & 3 & 5 & 6 & 8 & 8 & 8 & 9 & 9 & 1 & 1 & 1 & 1 & 1 & 1 & 1 & 1 & 1 & 1 & 1 & 1 & 1 & 1 & 1 & 1 & 1 & 1 \\
\hline & 1 & 2 & 9 & 9 & 2 & 3 & 4 & 9 & 2 & 9 & 0 & 0 & 0 & 0 & 0 & 1 & 1 & 2 & 2 & 2 & 2 & 4 & 4 & 5 & 7 & 7 & 7 & 8 \\
\hline & & & & & & & & & & & 0 & 1 & 4 & 5 & 6 & 1 & 6 & 1 & 2 & 5 & 8 & 6 & 7 & 8 & 0 & 3 & 6 & 2 \\
\hline 37890 & $\mathrm{C}$ & $\mathrm{T}$ & $\mathrm{G}$ & $\mathrm{C}$ & $\mathrm{T}$ & $\mathrm{T}$ & $\mathrm{G}$ & A & $\mathrm{C}$ & $\mathrm{C}$ & $\mathrm{T}$ & $\mathrm{C}$ & A & A & $\mathrm{T}$ & A & A & $\mathrm{C}$ & $\mathrm{C}$ & $\mathrm{G}$ & $\mathrm{G}$ & A & $\mathrm{C}$ & A & $\mathrm{T}$ & $\mathrm{C}$ & $\mathrm{T}$ & A \\
\hline 37891 & . & . & . & . & . & . & . & . & . & . & . & . & . & . & . & . & . & . & . & . & . & . & . & . & . & . & . & . \\
\hline Acin & . & . & . & . & . & . & . & . & . & . & . & . & . & . & . & . & . & . & . & . & . & . & . & . & . & . & . & . \\
\hline 1883 & . & . & . & . & . & . & . & . & . & . & . & . & . & . & . & . & . & . & . & . & . & . & . & . & . & . & . & . \\
\hline Lper & . & . & . & . & $\mathrm{C}$ & . & A & G & . & . & . & $\mathrm{T}$ & G & G & . & G & . & . & . & A & A & . & . & $\mathrm{T}$ & $\mathrm{C}$ & . & $\mathrm{C}$ & G \\
\hline Acap & A & $\mathrm{C}$ & . & . & . & $\mathrm{C}$ & A & $\mathrm{G}$ & . & $\mathrm{T}$ & $\mathrm{C}$ & . & . & G & $\mathrm{C}$ & G & . & $\mathrm{T}$ & A & . & A & . & . & . & $\mathrm{C}$ & $\mathrm{T}$ & $\mathrm{C}$ & . \\
\hline 1962 & A & $\mathrm{C}$ & . & . & . & $\mathrm{C}$ & A & $\mathrm{G}$ & . & $\mathrm{T}$ & $\mathrm{C}$ & . & . & G & $\mathrm{C}$ & G & . & $\mathrm{T}$ & A & . & A & . & . & . & $\mathrm{C}$ & $\mathrm{T}$ & $\mathrm{C}$ & . \\
\hline Llut & A & . & A & $\mathrm{T}$ & $\mathrm{C}$ & $\mathrm{C}$ & A & . & A & . & . & . & . & G & $\mathrm{C}$ & . & $\mathrm{T}$ & $\mathrm{T}$ & A & A & A & G & $\mathrm{T}$ & . & . & $\mathrm{T}$ & $\mathrm{C}$ & G \\
\hline \multirow[t]{4}{*}{43414} & A & . & A & $\mathrm{T}$ & $\mathrm{C}$ & $\mathrm{C}$ & A & . & A & . & . & . & . & G & $\mathrm{C}$ & . & $\mathrm{T}$ & $\mathrm{T}$ & A & A & A & G & $\mathrm{T}$ & . & . & $\mathrm{T}$ & $\mathrm{C}$ & G \\
\hline & 1 & 1 & 1 & 2 & 2 & 2 & 2 & 2 & 2 & 2 & 2 & 2 & 2 & 2 & 2 & 2 & 2 & 2 & 2 & 2 & 2 & 2 & 2 & 2 & 3 & 3 & 3 & 3 \\
\hline & 8 & 9 & 9 & 0 & 0 & 1 & 1 & 2 & 2 & 2 & 3 & 3 & 3 & 4 & 4 & 5 & 6 & 6 & 7 & 7 & 8 & 8 & 8 & 9 & 0 & 0 & 0 & 0 \\
\hline & 7 & 4 & 7 & 6 & 9 & 2 & 5 & 1 & 4 & 7 & 0 & 3 & 9 & 2 & 8 & 4 & 3 & 9 & 3 & 5 & 1 & 2 & 5 & 0 & 0 & 2 & 5 & 6 \\
\hline 37890 & G & A & $\mathrm{C}$ & G & $\mathrm{T}$ & $\mathrm{G}$ & $\mathrm{G}$ & $\mathrm{C}$ & A & $\mathrm{C}$ & A & $\mathrm{C}$ & $\mathrm{T}$ & $\mathrm{G}$ & $\mathrm{T}$ & $\mathrm{C}$ & $\mathrm{G}$ & A & $\mathrm{C}$ & A & A & A & $\mathrm{C}$ & $\mathrm{T}$ & $\mathrm{C}$ & A & $\mathrm{C}$ & G \\
\hline 37891 & . & . & . & . & . & . & . & . & . & . & . & . & . & . & . & . & . & . & . & . & . & . & . & . & . & . & . & . \\
\hline Acin & . & . & . & . & . & . & . & . & . & . & . & . & . & . & . & . & . & . & . & . & . & . & . & . & . & . & . & . \\
\hline 1883 & . & G & . & . & . & . & . & . & . & . & . & . & . & . & . & . & . & . & . & G & . & . & . & . & . & . & . & . \\
\hline Lper & . & . & $\mathrm{T}$ & . & . & A & A & . & . & . & . & . & . & A & $\mathrm{C}$ & . & A & $\mathrm{G}$ & $\mathrm{T}$ & G & . & . & $\mathrm{T}$ & $\mathrm{C}$ & . & . & . & A \\
\hline Acap & . & . & . & A & $\mathrm{C}$ & A & A & . & G & $\mathrm{T}$ & . & $\mathrm{T}$ & $\mathrm{C}$ & . & $\mathrm{C}$ & . & A & . & . & . & G & . & $\mathrm{T}$ & $\mathrm{C}$ & $\mathrm{T}$ & G & . & A \\
\hline 1962 & . & . & . & A & $\mathrm{C}$ & A & A & . & G & $\mathrm{T}$ & . & $\mathrm{T}$ & $\mathrm{C}$ & . & $\mathrm{C}$ & . & A & . & . & . & G & . & $\mathrm{T}$ & $\mathrm{C}$ & $\mathrm{T}$ & G & . & A \\
\hline Llut & A & . & . & A & . & A & A & $\mathrm{T}$ & . & . & G & . & $\mathrm{C}$ & A & $\mathrm{C}$ & $\mathrm{T}$ & $\mathrm{T}$ & . & $\mathrm{T}$ & G & . & G & . & $\mathrm{C}$ & . & . & $\mathrm{T}$ & A \\
\hline 43414 & A & . & . & A & . & A & A & $\mathrm{T}$ & . & . & G & . & $\mathrm{C}$ & A & $\mathrm{C}$ & $\mathrm{T}$ & $\mathrm{T}$ & . & $\mathrm{T}$ & G & . & G & . & $\mathrm{C}$ & . & . & $\mathrm{T}$ & A \\
\hline
\end{tabular}

Museum specimens from Chicago (Table 1) were wild otters caught by the same collector on the same day and locality in Laos. They were a few-week-old individuals; hence, their identification could have hardly been more than an hypothesis (L Heaney, pers. com. to F Barbanera, 2014). Likely, these otters were litter mates, as supported by the fact they hold the same $A$. cinereus mtDNA Cyt- $b$ haplotype (see Results). Samples from two additional wildcaught juvenile otters collected during the same expedition in the same area were borrowed from the Chicago museum. They proved to be genuine L. perspicillata otters when their mtDNA was sequenced in Pisa (MORETTI etal., in preparation). Therefore, on the one hand, sympatric occurrence of A. cinereus and L. perspicillata in Laos has been confirmed. On the other hand, we suggest that young representatives of these species cannot be reliably identified on a morphological basis (skull). The two species, indeed, show very similar brain structure (RADINSKY, 1968; WILLEMSEN, 1980), which is in agreement with their strict phylogenetic relationships proved by KOEPFLI et al. (2008a), who eventually suggested including them both in the genus Amblonyx (RAFINESQUE, 1832).

Museum specimens from Paris (Table 1) led to very different outcomes. Specimen MNHNZM-MO 1883-1295 was collected on the island of Palawan (Philippines), less than $300 \mathrm{~km}$ away from Malaysian Borneo (Sabah Province). The latter represents the easternmost edge of current smooth-coated otter distribution range (YOXON \& YOXON, 2014). Hence, we were particularly interested in this specimen to assess if $L$. perspicillata formerly occurred in the 

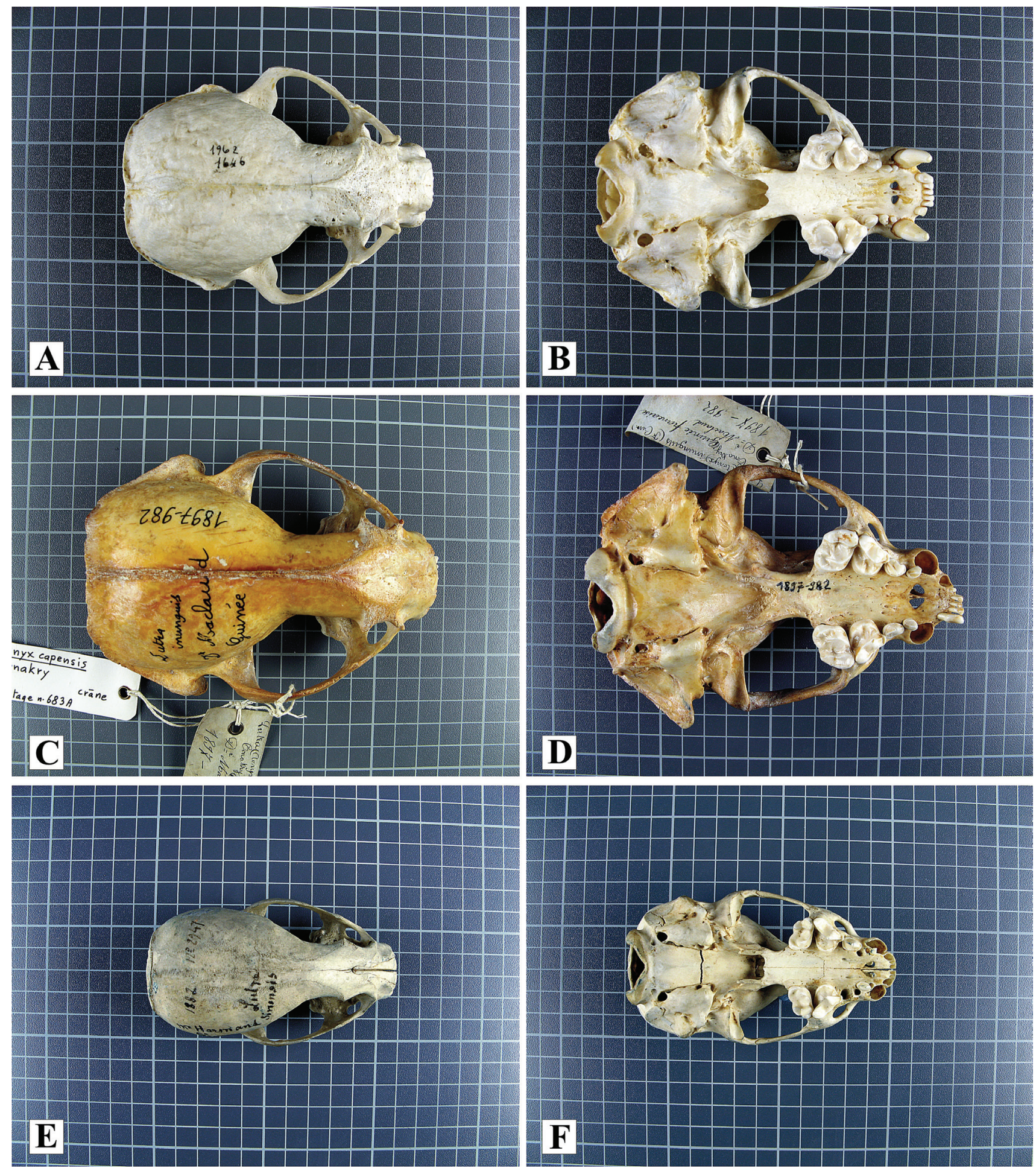

Fig. 2. - Dorsal (left) and ventral (right) skull views of: A-B. Misidentified MNHN-ZM-MO 1962-1646 specimen (unknown locality, Indochina). C-D. Aonyx capensis CG 1897-982 (Conakry, Guinea). E-F. Lutrogale perspicillata CG 1882-2947 (unknown locality, Thailand). All specimens are resident in the mammal collection of the National Museum of Natural History of Paris. Photos: courtesy of Geraldine Veron (researcher and curator of mammal collection). Scale: $1 \mathrm{~cm}$. 
western Philippine islands as well. By using a sample obtained from a study skin, we found that MNHN-ZM-MO 1883-1295 belonged to the species $A$. cinereus. Later, we became aware that the skull of the same specimen, preserved separately from the skin, had been catalogued as $A$. cinereus, thus confirming the reliability of the genetic result ( $\mathrm{G}$ Veron, pers. com. to F Barbanera, 2014). Furthermore, researchers in the Philippines confirmed the absence of L. perspicillata in Palawan, the Asian smallclawed being the only otter recorded so far (LSG Castro \& DAP Fernandez, pers. com. to F Barbanera, 2015).

As far as the second specimen (MNHNZM-MO 1962-1646) from Paris is concerned, we found that it was not L. perspicillata from Indochina but an African clawless otter (A. capensis). This result came as a big surprise, but it was confirmed following a morphological comparison between the skull of the specimen in point (Fig. 2: A, B) and those of real A. capensis and L. perspicillata kept in the same collection (Fig. 2: $\mathrm{C}$ to F). To summarize, A. capensis (Fig. 2: C, D) has a broader and more rounded brain case than L. perspicillata (Fig. 2: E, F). The latter is evenly ovoid and much deeper than wide, with a high rostrum (blunt in A. capensis). Aonyx capensis has wider orbits and shorter zygomata (with wide and prominent posterior temporal process) than $L$. perspicillata. The infraorbital foramen is rounded in A. capensis and kidneyshaped in L. perspicillata, and deeper in the first than in the second. The anterior palatine foramen is wide and subtriangular in shape in A. capensis while it is small and rounded in L. perspicillata; the sagittal crest is placed upward in $A$. capensis while it is low in L. perspicillata (cf. HARRISON \& BATES, 1991).

NMW 43414 otter skin from Vienna, the most recently collected specimen (1978) of this study (Table 1), was bought at the market of Kathmandu, Nepal. Regrettably, no further information was available. We assigned this specimen to L. lutra. Smooth-coated differs from Eurasian otter in having a more massive head and heavier teeth, shorter and smoother fur, sleek appearance, and dorsoventrally rather than circular flattened tail tip (HWANG \& LARIVIÈRE, 2005). However, otter identification can be difficult, especially when based only on old and/or not well-preserved dry skin. As reported by AL-SHEIKHLY \& NADER (2013), who made morphometric analyses of skins from dead otters in order to prove the persistence of $L$. p. maxwelli subspecies in Iraq, loss of pelage colour is common in old specimens and creates a similar appearance to Eurasian and smooth-coated otters. Nevertheless, skin of both species can be reliably identified by inspecting rhinarium and eyehole position. In the smoothcoated otter, the upper border of the rhinarium shows a well-defined hairline, which is much straighter than in the Eurasian otter. In the latter, it appears as convex. Furthermore, in the smoothcoated otter the eyehole is placed more anteriorly and considerably lower down in the face when compared to the Eurasian otter (HARRISON \& BATES, 1991).

As comprehensively discussed by RASMUSSEN \& PRÎJJONES (2003), there is a wide range of ways through which misinformation can spread across museum collections, spanning from casual errors and careless labelling to commercial imprecision, incompetence (inadequate training and/or supervision of collectors), inappropriate curatorial techniques, problems in deciphering and interpreting data, and even fraud. Regrettably, detecting such errors can be extremely challenging. As interestingly noted by BOESSENKOOL et al. (2010), investigation on doubtful specimens is usually undertaken when they are from a suspicious collector, form outliers with respect to the natural distribution range of a given taxon, or show an unconvincing collection date (e.g., after a species was reported to be extinct). With reference to our study, we do not have enough information to disentangle how mistakes occurred. Chicago specimens were baby otters, and morphological approach for their identification proved to be unreliable. Despite concern that MNHN-ZM-MO 1883-1295 from the Philippines could be a suspicious outlier on the basis of present-day distribution range of 
L. perspicillata, the error was detected only after DNA investigation, which prevented its wrong incorporation into any future report on historical diversity patterns of the species. Possibly, the separation of skin and skeletal remains in the collection did not help earlier disclosure of such erroneous labelling. Finally, wrong identification of the second specimen from Paris and of that from Vienna was possibly due to incompetence of collectors and subsequent carelessness of curators. Indeed, as reported above, dissimilarity between L. perspicillata and L. lutra/A. capensis should have been acknowledged. NMW 43414 wrong labelling could have originated also from dealers, as they usually prioritise profit over the correct identity of the item (RASMUSSEN \& PRÎJJONES, 2003). Nevertheless, misidentification was perpetuated when the presently retired curators in Vienna determined the NMW 43414 skin as Lutrogale.

Historical material is a limited resource and museum sampling for molecular DNA use is a destructive procedure. Criteria for the approval of loans have been discussed since the early 1990s (e.g., Р Ӓ̈̈BO et al., 1992). Revealing errors in museum specimens can be very challenging when the investigation is mostly based on collectors' notes, data and preparatory techniques (BOESSENKOOL et al., 2010). The ever-increasing results provided by the use of biotechnological methods suggest that the information obtained through DNA analyses may add huge value to a given specimen and/or museum collection. We encourage curators to pursue a multidisciplinary approach, including DNA analyses, to properly archive the resources of biodiversity under their management, and researchers to endorse full responsibility justifying their need for destructive sampling.

\section{ACKNOWLEDGEMENTS}

For tissue loan and information on specimen history we are deeply grateful to: W. Stanley (Director of collections), L Heaney (Mammal collection curator), R Banasiak (Research assistant) and $\mathrm{J}$ Phelps (Assistant collection manager) at the Field Museum of Natural History, Chicago, USA; G Veron (Researcher and mammal collection curator) at the National Museum of Natural History, Paris, France; F Zachos (Head of mammal collection) and A Bibl (Mammal collection manager) at the Natural History Museum, Vienna, Austria. Authors are deeply grateful to $\mathrm{G}$ Veron for skull pictures of $A$. cinereus, $L$. perspicillata and MNHN-ZM-MO 1962-1646 specimens at the National Museum of Natural History of Paris. We also thank LSG Castro (College of Fisheries and Aquatic Sciences, Western Philippines University, Puerto Princesa) and DAP Fernandez (Institute of Biological Sciences, University of the Philippines, Los Baños) for information on Palawan otters. This research is part of a project funded by the National Geographic Society Conservation Trust (USA) with grant \#C26113 to F.B. and by the University of Pisa (Italy) with "Progetto di Ricerca di Ateneo" grant \#PRA_2016_1.

\section{REFERENCES}

Al-SheikHly OF, MukHTAR KH, Barbanera F, CSORBA G \& HARRISON DL (2015a). Checklist of the Mammals of Iraq (Chordata: Mammalia). Bonn zoological Bulletin, 64: 33-58.

Al-SHEIKHLY OF, MuKHTAR KH \& BARBANERA F (2015b). Recent sighting of smooth-coated otter Lutrogale perspicillata maxwelli in Hawizeh marsh (southern Iraq). IUCN Otter Specialist Group Bulletin, 32: 30-32.

AL-SHEIKHLY OF \& NADER AI (2013). The status of Iraq Smooth-Coated Otter Lutrogale perspicillata maxwelli Hayman 1956 and Eurasian otter Lutra lutra Linnaeus 1758 in Iraq. IUCN Otter Specialist Group Bulletin, 30: 18-30.

BARNETT R, YAMAGUCHI N, SHAPIRO B \& NIJMAN V (2007). Using ancient DNA techniques to identify the origin of unprovenanced museum specimens, as illustrated by the identification of a 19th century lion from Amsterdam. Contributions to Zoology, 76: 87-94.

Bi K, Linderoth T, VANDERPoOl D, GoOd JM, NIELSEN R \& MORITZ C (2013). Unlocking 
the vault: next generation museum population genomics. Molecular Ecology 22, 6018-6032.

BOESSENKOOL S, STAR B, SCOFIELD RP, SEDDON PJ \& WATERS JM (2010). Lost in translation or deliberate falsification? Genetic analyses reveal erroneous museum data for historic penguin specimens. Proceedings of the Royal Society B: Biological Sciences 277: 10571064.

de Moraes Barros N, Silva JAB \& Morgante JS (2011). Morphology, molecular phylogeny, and taxonomic inconsistencies in the study of Bradypus sloths (Pilosa: Bradypodidae). Journal of Mammalogy, 92: 86-100.

ForCINA G, GUERRINI M, VAN GROUW H, GUPTA BK, PANAYIDES P, HADJIGEROU P, AL-SHEIKHLY OF, AWAN MN, KHAN AA, ZEDER MA \& BARBANERA F (2015). Impacts of biological globalization in the Mediterranean: Unveiling the deep history of human mediated game bird dispersal. Proceedings of the National Academy of Sciences of the Unites States of America, 112: 3296-3301.

GEE H (1988). Natural History Museum to build DNA database in London. Nature, 336: 707.

GRAVES GR \& BRAUN MJ (1992). Museums: Storehouses of DNA? Science, 255: 1335-1336.

GUINDON S, DUFAYARD JF, LEFORT V, ANISIMOVA M, HORDIJK W \& GASCUEL O (2010). New algorithms and methods to estimate maximum-likelihood phylogenies: assessing the performance of PhyML Systematic Biology, 59: 307-321.

HALL TA (1999). BioEdit: a user-friendly biological sequence alignment editor and analysis program for Windows 95/98NT. Nucleic Acids Symposium Series, 41: 95-98.

HARRISON DL \& BATES PJJ (1991). The Mammals of Arabia. Harrison Zoological Museum, Sevenoaks, Kent, UK.

Higuchi R, Bowman B, Freiberger M, Ryder OA \& WILSON AC (1984). DNA sequences from the quagga, an extinct member of the horse family. Nature, 312: 282-284.

Hussain SA, DE Silva PK \& Mostafa Feeroz M (2008). Lutrogale perspicillata. The IUCN Red List of Threatened Species. Version 2014.3. Downloaded on 14 March 2015, www.iucnredlist. org.

HWANG YT \& LARIVIÈRE S (2005). Lutrogale perspicillata. Mammalian Species, 786: 1-4.
Koblik EA, Red'KIn YA, MeER MS, DeRelle R, GOLENKINA SA, KONDRASHOV FA \& ARKHIPOV VY (2011). Acrocephalus orinus: A Case of Mistaken Identity. PLoS One, 6: e17716.

Koepfli K-P, Kanchanasaka B, Sasaki H et al. (2008a). Establishing the foundation for an applied molecular taxonomy of otters in Southeast Asia. Conservation Genetics, 9: 1589-1604.

Koepfli K-P, DeERe KA, SLAter GJ et al. (2008b). Multigene phylogeny of the Mustelidae: resolving relationships, tempo and biogeographic history of a mammalian adaptive radiation. BioMed Central Biology, 6:10.

LEE PM, GRIFFITHS R (2003). Sexing errors among museum skins of a sexually monomorphic bird, the Moorhen Gallinula chloropus. Ibis, 145: 695698.

Lerone L, Mengoni C, CARPANETo GM, RANDi E \& LOY A (2014). Procedures to genotype problematic non-invasive otter (Lutra lutra) samples. Acta Theriologica, 59: 511-520.

Lister AM, Climate Change Research Group (2011). Natural history collections as sources of long-term datasets (2011). TRENDS in Ecology and Evolution, 26: 153-154.

LOPEZ J, YUHKI N, MASUdA R, MODI W \& O'BRIEN SJ (1994). Numt, a recent transfer and tandem amplification of mitochondrial DNA to the nuclear genome of the domestic cat. Journal of Molecular Evolution, 39:174-190.

Müller L, Gonçalves GL, Cordeiro-Estrela P, MARINHO JR, ALthofF SL, Testoni AF, GONZÁLEZ EM \& FREITAS TRO (2013). DNA Barcoding of Sigmodontine Rodents: Identifying Wildlife Reservoirs of Zoonoses. PLoS One, 8: e80282.

PÄÄBO S, GIFFORD JA \& WILSON AC (1988). Mitochondrial DNA sequences from a 7000-year old brain. Nucleic Acids Research, 16: 97759787.

PÄÄBo S, WAYNE R \& ThOMAS R (1992). On the use of museum collections for molecular genetic studies. Ancient DNA Newsletter, 1: 4-5.

Pergams ORW \& LACY RC (2008). Rapid morphological and genetic change in Chicagoarea Peromyscus. Molecular Ecology, 17: 450463.

RASMUSSEN PC \& PRŶS-JONES RP (2003). History vs mystery: The reliability of museum specimen 
data. Bulletin of The British Ornithologists' Club, 123A: 66-94.

RAWLENCE NJ, KenNedy M, WATERS JM \& SCOFIELD RP (2014). Morphological and ancient DNA analyses reveal inaccurate labels on two of Buller's bird specimens. Journal of the Royal Society of New Zealand, 44: 163-169.

RoBins JH, TinTINGER V, APLIN KP, HiNGSTON M, Matisoo-Smith E, Penny D \& LaVery SD (2014). Phylogenetic species identification in Rattus highlights rapid radiation and morphological similarity of New Guinean species. PLoS One, 9: e98002.

STUART BL \& FRITZ U (2008). Historical DNA from museum type specimens clarifies diversity of Asian leaf turtles (Cyclemys). Biological Journal of the Linnean Society, 94: 131-141.

SuAREZ AW \& TsuTsui ND (2004). The Value of Museum Collections for Research and Society. BioScience, 54: 66-74.

TAMURA K \& NeI M (1993). Estimation of the number of the nucleotide substitutions in the control region of mitochondrial DNA in humans and chimpanzees. Molecular Biology and Evolution, 10: 512-526.

Tamura K, Peterson D, Peterson N, Stecher G, NeI M \& Kumar S (2011). MEga5: Molecular Evolutionary Genetics Analysis using Maximum Likelihood, Evolutionary Distance, and Maximum Parsimony Methods. Molecular Biology and Evolution, 28: 2731-2739.
THOMAS RH (1994). Analysis of DNA from natural history museum collections. Molecular Ecology and Evolution: Approaches and Applications, 69: 311-321.

THOMAS RH, SCHAFFNER W, WILSON AC \& PÄÄBO S (1989). DNA phylogeny of the extinct marsupial wolf. Nature, 340: 465-467.

Thompson JD, Gibson TJ, Plewniak F, JeAnMOUGIN F \& Higgins DG (1997). The ClustalX windows interface: Flexible strategies for multiple sequence alignment aided by quality analysis tools. Nucleic Acids Research, 24: 4876-4882.

Vianna JA, Medina-Vogel G, Chehebar C, SiElFEld W, OlAVARRÍA C \& FAUGERON S (2011). Phylogeography of the Patagonian otter Lontra provocax: adaptive divergence to marine habitat or signature of southern glacial refugia? BioMed Central Evolutionary Biology, 11: 53.

WANDELER P, HOECK PEA \& LUKAS FK (2007). Back to the future: museum specimens in population genetics. TRENDS in Ecology and Evolution, 22: 634-642.

WeSCHELER L (1995). Mr. Wilson's Cabinet of Wonders. Vintage Books, New York, USA.

YOXON P \& YOXON GM (2014). Otters of the world. Whittles Publishing, Dunbeath, UK.

Received: 10 February 2016

Accepted: 13 June 2016

Branch editor: Kurt Jordaens 